\title{
列車の単線並列運転を支援する軌道の分岐構造の開発
}

\author{
玉川 新悟*1, 清水 紗希*1, 三原 輝久 ${ }^{* 2}$, 及川 祐也 ${ }^{* 2}$
}

\section{Switch and crossing for single line operation at double track section}

\author{
Shingo TAMAGAWA ${ }^{* 1}$, Saki SHIMIZU*1, Teruhisa MIHARA*2 and Yuya OIKAWA ${ }^{* 2}$ \\ ${ }^{* 1,{ }^{*}}$ Track Technology Division, Railway Technical Research Institute \\ 2-8-38 Hikari-cho, Kokubunji-shi, Tokyo 185-8540, Japan
}

Received: 1 March 2020; Revised: 8 May 2020; Accepted: 25 May 2020

\begin{abstract}
This study aims to develop the switch and crossing for a single line operation at the double track section. First, the authors design and produce the simplified structure of the switch and crossing for passenger trains which can be installed without the cutting of the existing rails. Secondly, we test the fatigue durability of the front end of the structure by rolling fatigue test device. As a result, the sufficient durability is verified under the condition that the design use period is one month and the total annual axle loads are $1.0 \times 10^{8} \mathrm{kN}$. Thirdly, we perform the running test of the motor car on the product installed at the test track and confirm that the motor car can pass over the structure at the maximum speed $15 \mathrm{~km} / \mathrm{h}$. Fourthly, we perform the vehicle running simulation based on FEM and confirm the running safety of the structure from the point of view of the stress generated at the components, the derailment coefficient and the decrease ratio of wheel loads. Finally, we test the fatigue durability of the specimen and conclude that the welding part of the turn rail and bed plates, the spring for turning rails and rail fastenings have a practically sufficient durability.
\end{abstract}

Keywords : Railway track, Switch and crossing, Single line operation, Running safety, Fatigue durability, FEM

\section{1. 緒言}

近年，旅客の利便性の向上と輸送障害時の輸送力の確保の観点から，情報ネットワークを活用して，列車の制 御と運行管理の機能を一体化した柔軟な列車運行システムの開発が検討されている(杉山他，2018)。このような 柔軟な列車運行を実現するうえで，複線の片方の線路の一部区間に運行の支障が生じた場合に，もう片方の線路 で双方向に列車を運行させる単線並列運転（富井，2012）を実現する技術は，重要な要素技術となる．また，単 線並列運転の実現は，従来の作業時間帯にとらわれない効率的な線路工事等を可能とし，将来的に懸念される労 働力不足への対策効果が期待できる.

単線並列運転の実現において軌道に要求される技術としては，図 1 に示すように工事区間の前後に設置し，工 事期間中に一時的に使用する軌道の分岐構造が考えられる。本分岐構造について，既存の分岐器(及川，2016)を 適用した場合，敷設時に既設レールの切断と再接合による付帯工事が生じるため，単線並列運転の実現による費 用面での優位性が損なわれる。また，既存の分岐器は，年に複数回の保守検査の実施が規定されているため，敷 設後の保守管理に多大な労力が必要となる. 一方で, 既存の分岐器を簡略化し, 保守管理の労力が小さい構造と して横取り装置(石野，2016)がある，横取り装置は，既設レールの上に車輪乗り越し用のレールを被せ，分岐さ せる構造を有する。しかしながら，本装置は保守用車両の通過を前提としているため，車両と軌道の接触防止の ための離隔確保の観点から，営業列車の通過を前提とした分岐構造には採用できない.また，分岐線側の最大通 過速度を $5 \mathrm{~km} / \mathrm{h}$ に制限しているため，営業線に必要な輸送力を確保するのは困難である.

本研究では，単線並列運転を軌道側から支援する技術として，営業列車の通過を前提としたうえで，敷設時の

No.20-00065 [DOI:10.1299/transjsme.20-00065], J-STAGE Advance Publication date : 2 June, 2020

*1 正員，鉄道総合技術研究所 軌道技術研究部（一185-8540 東京都国分寺市光町 2-8-38）

*2 鉄道総合技術研究所 軌道技術研究部

E-mail of corresponding author: tamagawa.shingo.15@rtri.or.jp 
既設レールの切断を不要とし，敷設後の保守管理を省力化した新しい分岐構造を開発することを目的とする. 本 稿では，新しい分岐構造を設計・製作するとともに，提案した構造について，車両が脱線することなく安定して 通過するための走行安全性と，車両からの荷重に対する部材強度を評価した結果を示す.

なお，本稿では鉄道分野の技術用語として，静止した鉄道車両の一対の左右車輪からレールに作用する鉛直荷 重の和を「軸重, Axel load」と称する. また，走行車両の片方の車輪からレールに作用する鉛直荷重と水平荷重 をそれぞれ「輪重, Wheel load」,「横圧, Lateral load」と称し，前者は鉛直下向きに作用する方向を正，後者は軌 間の内側から外側へ作用する方向を正とする. また，分岐構造のなかで， 1 つの軌道を 2 つに分ける部分のこと を「ポイント部, Switch panel」, 分かれた 2 つの軌道が公差する部分を「クロッシング部, Crossing panel」と称 する．その他，分岐構造の各部材の名称等については，文中で説明を加える.

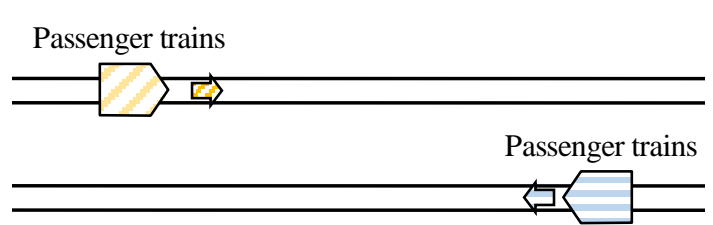

(a) Double line operation
Switches \& crossings Construction section Switches \& crossings

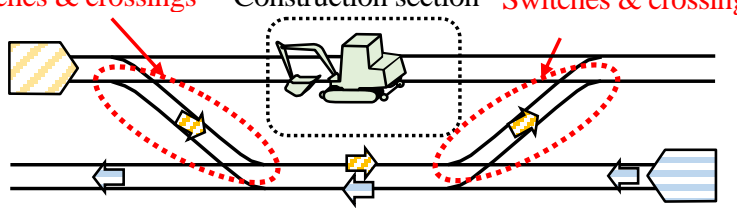

(b) Single line operation at double track section

Fig.1 Image of the single line operation at double track section by introduction of the switches and crossings. The switches and crossings enable the passenger trains to evade the construction section at double track section. The simplified structure is required for passenger trains which can be installed without the cutting of the existing rails.

\section{2. 基本構造の検討と問題点の抽出}

\section{$2 \cdot 1$ 開発のコンセプト}

前章に示した背景に則り，開発する分岐構造のコンセプトを以下のとおりとした.

- 営業列車が通過可能な構造

$>$ 営業列車の通過に必要な走行安全性と部材強度を有する

$>$ 在来線の下級線区で，軌道や下部構造物の大規模工事期間中の連続使用を想定する

• 必要な箇所に事前に敷設し, 必要時に列車の進行方向を切り替え可能な構造

$>$ 敷設時に既設レールの切断は不要とし, 既設の軌道に後付けで設置可能な構造とする

$>\quad$ 必要時に単線並列運転に切り替え可能な簡略構造とし，保守管理の省力化が図れるものとする

上記のコンセプトを踏まえ,設計の荷重条件を表 1 に示すとおりとした.年間に通過する車両の軸重の合計は, 在来線の下級線区を想定し， $1.0 \times 10^{8} \mathrm{kN}$ とした．また，連続使用期間は，軌道や下部構造物の大規模工事を想定 して最大 1 ケ月間とした. 車両の最大軸重は，一般的な分岐構造の設計に用いられる $150 \mathrm{kN}$ (鉄道総合技術研究 所, 2012) とした.

Table 1 Load conditions for the switch and crossing. The conditions are based on the concept of the structures. The total annual axle load of trains assumes the use of the lower class lines and the maximum period of the continuous use assumes the large-scale track construction. The value of the maximum axle load of trains is commonly used in the design of the switches and crossings.

\begin{tabular}{c|c}
\hline Item & Values \\
\hline Total annual axle load of trains & $1.0 \times 10^{8} \mathrm{kN}$ \\
\hline Maximum period of the continuous use & One month \\
\hline Maximum axle load of trains & $150 \mathrm{kN}$ \\
\hline
\end{tabular}




\section{$2 \cdot 2$ 基本構造の検討（初期設計）}

前節のコンセプトに基づき, 基本構造の検討を行った.ここでは，当該構造の平面線形を検討するにあたり， 既存の 8 番可動式横取り装置(柳川，2020)を参考とした. 本装置を参考とした理由は，一部の既存部材の共有化 が図れるのに加え，一般的に使用される分岐構造のなかで最も番数が小さいため，全体の構造を短くし，材料費 の低減が図れるためである. 図 2 に初期設計時のポイント部を示す．本構造は，既設の PC まくらぎを部分的に 分岐構造用の長尺まくらぎ（以下，「分岐まくらぎ，Bearer」）に置き換え，分岐まくらぎに転換式のレール（以 下，「転換レール，Turn rail」）を 2 本設置した構造としている. 転換レールが分岐線側の誘導用の支持レール（以 下，「支持レール，Support rail」），分岐線側の新設レール（以下，「分岐レール，Branch rail」）および既設レール に被さることで単線並列運転用の分岐線となる．転換レールは，その転換部を 2 本の分岐まくらぎに固定してい る.また，転換レールが既設レールに被さる構造であるため，既設レールと転換レールの先端部には，転換レー ルの厚さに応じた段差が生じる. 段差量は, 類似の構造を有する既存の横取り装置が $6 \mathrm{~mm}$ であるのに対し, 車 輪通過時の衝撃緩和と部材強度の確保および製作精度の観点から $3 \mathrm{~mm}$ を目標值とした. 分岐線側の最高通過速 度は，営業線に必要な輸送力を確保するため， $15 \mathrm{~km} / \mathrm{h}$ を目標値とした。使用材料は，転換レールを S45C（焼入 れ・焼き戻し処理），支持レールを SS400，分岐レールを既設レールと同じレール鋼（JIS 50kgN）とした．また， 分岐まくらぎは木まくらぎとした.

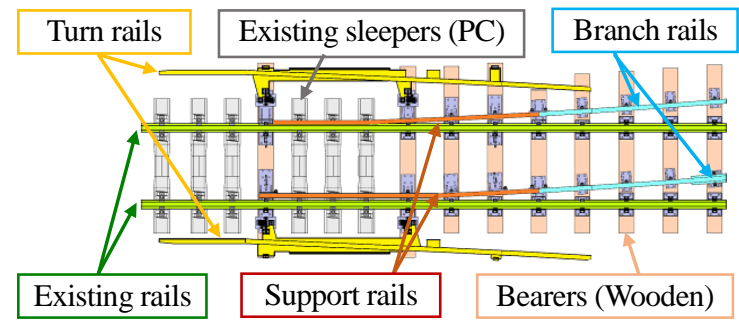

(a) Before switching

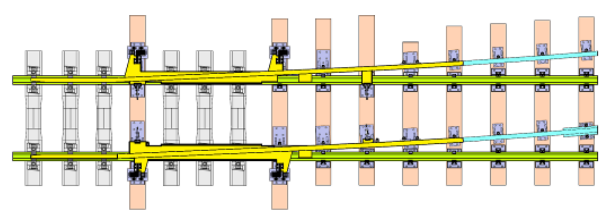

(b) After switching

Fig.2 Proposed structure of a switch panel at an initial design stage. The alignment of the proposed structure is designed by referring the existing structure.

\section{$2 \cdot 3$ 走行解析と問題点の抽出}

初期設計時の基本構造の課題を抽出するため, 車両の走行解析を実施した. ここでは, FEMに基づく鉄道車両 の走行解析手法（西宮，2018）を用いた． 既存の分岐構造の走行安全性の評価における本解析手法の有用性につ いては, 過去に著者らが確認している (Shimizu et al., 2019). FEM の解析ソルバーは, 汎用の解析ソフト「Virtual Performance Solution」を用いた. 図 3 に軌道の解析モデルを示す.ここでは, ポイント部の分岐線側を対象とし, 前節に示した軌道部材（既設レール，転換レール，支持レール，分岐レール）をソリッド要素とシェル要素でモ デル化し，まくらぎを梁要素，レール締結装置をばね要素，地盤やバラスト等のまくらぎ支持構造をばね要素で モデル化した，また，車両モデルは，図 4 に示すように，車体，台車，輪軸を剛体でモデル化し，軸ばね，まく らばね，車体と台車を接続する台車牽引リンクをばね要素とダンパ要素でモデル化した．また，車輪表面はソリ ッド要素でモデル化し，車輪とレールの接触判定は，ペナルティ法を用いた．表 2 に軌道の各ば叔定数と車両モ デルの主要諸元を示す. 車両の走行速度は目標值の $15 \mathrm{~km} / \mathrm{h}$ とし, 走行方向は軌道が分岐する方向 (以下, 「対向, Facing」）と合流する方向（以下，「背向，Trailing」）を設定した.

解析結果として, 図 5 に外軌側の転換レールの先端部と後端部における水平方向変位の時刻歴応答を示寸. 図 5 より, 転換レールの先端部（Point 1) は, 背向走行時に軌間外側へ最大 $25.4 \mathrm{~mm}$ 変位し, 転換レールの後端部

(Point 2) は, 対向走行時に軌間外側へ最大 $13.6 \mathrm{~mm}$ 変位している. 図6に背向走行時における車両と転換レ一 ルの挙動を示す．図 6 より，転換レールが水平方向に変位することで，車輪が既設レール上に乗り上がっている ことがわかる．転換レールの水平変位は，車両通過時の横圧により，転換レールの先端部と後端部が片持ち梁の 状態で押されることで生じている，このため, 車両の走行安全性と部材強度を確保するためには, 転換レールの 固定箇所数を増加させ，水平変位を抑制させる必要があることがわかる. 


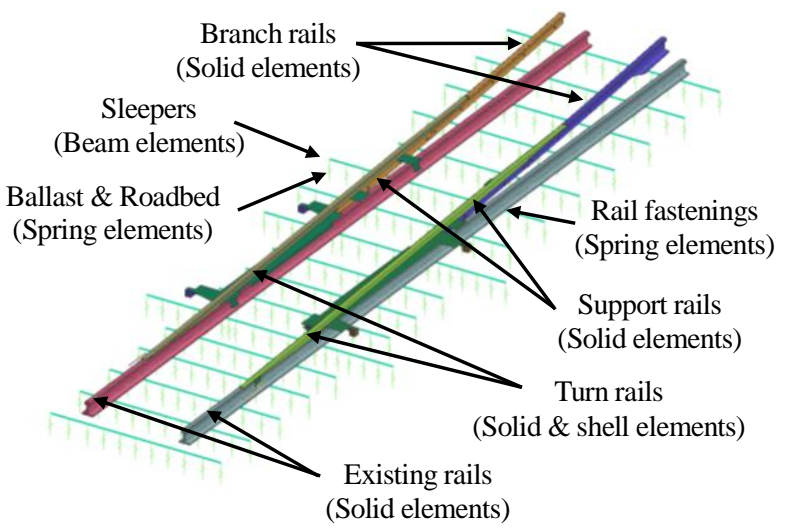

Fig.3 FEM model of the proposed structures at an initial design stage.

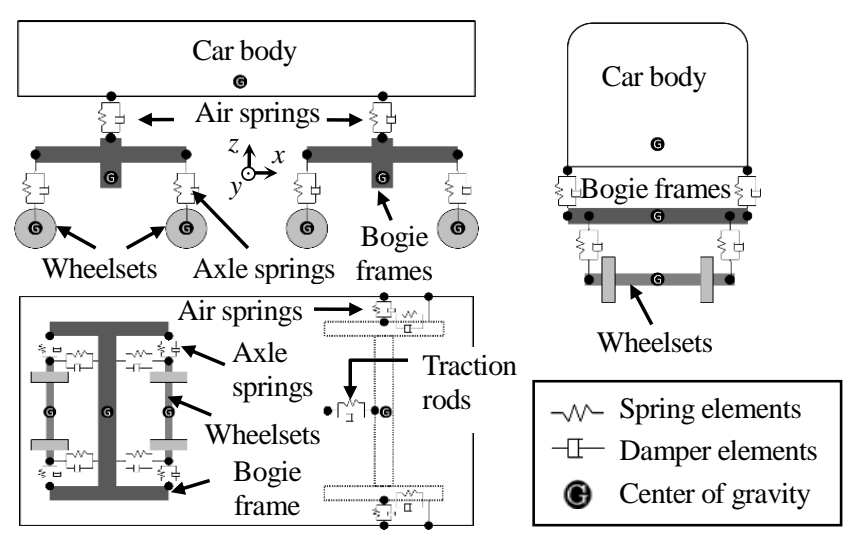

Fig.4 Vehicle model.

Table 2 Main parameters of the track and vehicle model.

(a) Track model

\begin{tabular}{c|c}
\hline Item & Values \\
\hline Young's modulus (Rail) & $2.1 \times 10^{5} \mathrm{~N} / \mathrm{mm}^{2}$ \\
\hline Poisson's ratio (Rail) & 0.3 \\
\hline Young's modulus (Sleeper) & $8.1 \times 10^{3} \mathrm{~N} / \mathrm{mm}^{2}$ \\
\hline Cross section area (Sleeper) & $3.36 \times 10^{4} \mathrm{~mm}^{2}$ \\
\hline Vertical moment of inertia of area of sleeper & $5.49 \times 10^{7} \mathrm{~mm}^{4}$ \\
\hline Lateral moment of inertia of area of sleeper & $1.61 \times 10^{8} \mathrm{~mm}$ \\
\hline Rail fastenings vertical springs & $2.0 \times 10^{3} \mathrm{kN} / \mathrm{mm}^{4}$ \\
\hline Ballast \& Roadbed vertical springs ${ }^{* 1}$ & $39 \mathrm{kN} / \mathrm{mm}$ \\
\hline Ballast \& Roadbed lateral springs ${ }^{* 1}$ & $1.6 \mathrm{kN} / \mathrm{mm}$ \\
\hline Ballast \& Roadbed longitudinal springs ${ }^{* 1}$ & $5.2 \mathrm{kN} / \mathrm{mm}$ \\
\hline "1 Spring coefficients are defined as the values per 1 $\mathrm{m}$ of the length of \\
the sleepers. \\
"2 The respective directions are defined in Fig.4.
\end{tabular}
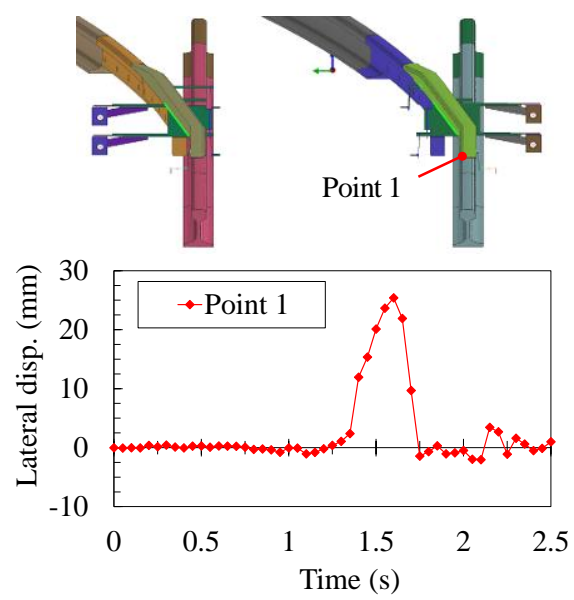

(a) Displacement of front end (trailing run) (b) Vehicle model

\begin{tabular}{|c|c|c|}
\hline \multicolumn{2}{|c|}{ Item } & Values \\
\hline \multicolumn{2}{|c|}{ Track gauge } & $1067 \mathrm{~mm}$ \\
\hline \multicolumn{2}{|c|}{ Distance between two bogies } & $14.4 \mathrm{~m}$ \\
\hline \multicolumn{2}{|c|}{ Wheelbase } & $2.1 \mathrm{~m}$ \\
\hline \multirow{3}{*}{ Axle springs } & $x$-direction ${ }^{* 2}$ & $6.03 \times 10^{-2} \mathrm{kN} / \mathrm{mm}$ \\
\hline & $y$ - direction ${ }^{* 2}$ & $5.07 \times 10^{-2} \mathrm{kN} / \mathrm{mm}$ \\
\hline & $z$ - direction ${ }^{* 2}$ & $1.12 \mathrm{kN} / \mathrm{mm}$ \\
\hline \multirow{3}{*}{ Air springs } & $x$ - direction ${ }^{* 2}$ & $1.84 \times 10^{-3} \mathrm{kN} / \mathrm{mm}$ \\
\hline & $y$ - direction ${ }^{* 2}$ & $1.84 \times 10^{-3} \mathrm{kN} / \mathrm{mm}$ \\
\hline & $z$ - direction ${ }^{* 2}$ & $1.26 \mathrm{kN} / \mathrm{mm}$ \\
\hline \multicolumn{2}{|c|}{ Coefficient of friction between rail and wheel } & 0.3 \\
\hline \multicolumn{2}{|c|}{ Suspended mass } & $5.22 \times 10^{4} \mathrm{~kg} / \mathrm{car}$ \\
\hline \multicolumn{2}{|c|}{ Mass between primary and secondary spring } & $1.5 \times 10^{3} \mathrm{~kg} /$ bogie \\
\hline \multicolumn{2}{|c|}{ Unsuspended mass } & $1.5 \times 10^{3} \mathrm{~kg} / \mathrm{axel}$ \\
\hline \multicolumn{2}{|c|}{ Axle loads } & $150 \mathrm{kN}$ \\
\hline
\end{tabular}

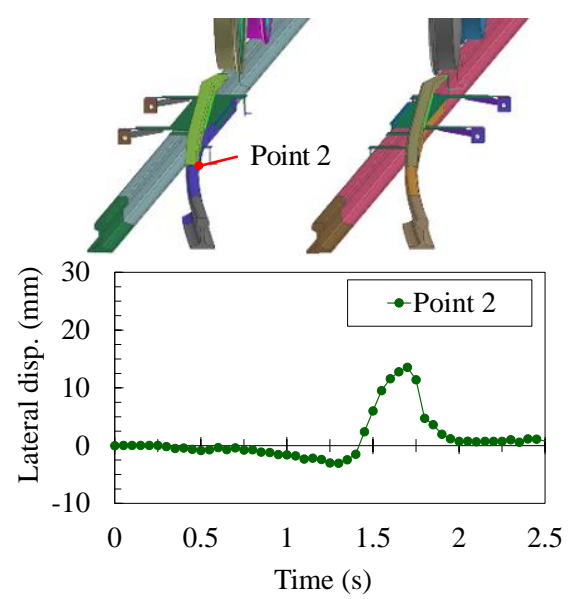

(b) Displacement of rear end (facing run)

Fig.5 Relationship between times and lateral displacements of front and rear end of the structure. The maximum displacement of the front end is $25.4 \mathrm{~mm}$ as shown in (a) and rear end is $13.6 \mathrm{~mm}$ as shown in (b). 


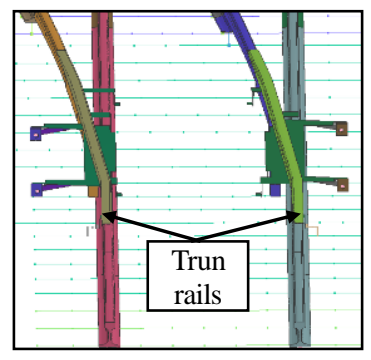

(a) Before passing of vehicle

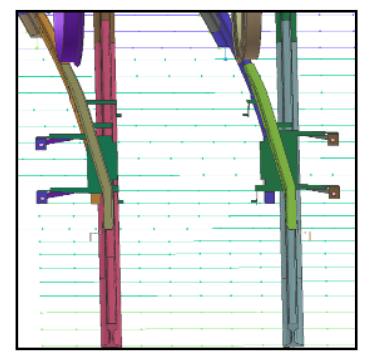

(b) Passing of vehicle at the rear end of turn rails

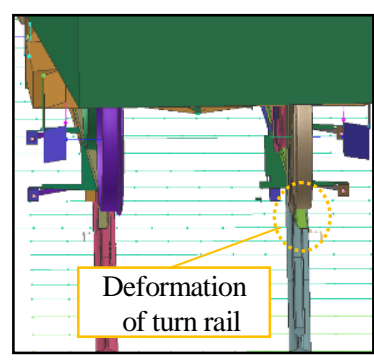

(c) Passing of vehicle at the front end of turn rails

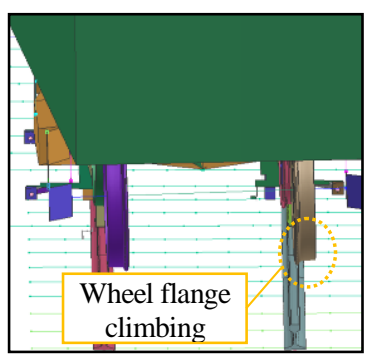

(d) After passing of vehicle at the front end of turn rails

Fig.6 FEM simulation of vehicle running at the proposed structure (trailing run). The wheel flange rides over the existing rail because of the deformation of the turn rail. In order to ensure the running safety, the number of the connections between turn rails and sleepers should be increased.

\section{$2 \cdot 4$ 転動疲労試験}

列車の繰返し走行に対する転換レールの先端部の而久性を確認するため,転動疲労試験を行った. 本試験では, 転換レールの先端部を模擬した試験体に対して，鉛直荷重を負荷した試験車輪をレールの長手方向に繰り返し往 復させた. 図 7 に試験状況を, 表 3 に試験条件を示寸。ここで, 前節の解析手法より, 軸重 $150 \mathrm{kN}$ （静止時の輪 重 $75 \mathrm{kN}$ ）の車両が $3 \mathrm{~mm}$ の転換レールの先端部を乗り上がる際の輪重を算定すると $139 \mathrm{kN}$ となる. そこで, 本 試験の鉛直荷重は, 図 8 に示すように, 試験車輪が転換レールの先端部を乗り上がる際の荷重が上記の解析值と 概ね一致するように設定した。なお，本試験では，車輪が転換レールに乗り上がる際の輪重が先端部に与える影 響に着目したため，横圧は考慮していない。

年間に通過する車両の軸重の合計が $1.0 \times 10^{8} \mathrm{kN}$ の線区で 1 カ月間連続使用する条件に相当する車輪通過回数は,

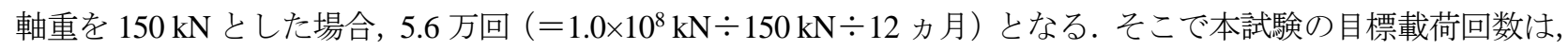
安全余裕を考慮して 6 万回（往復）とした.

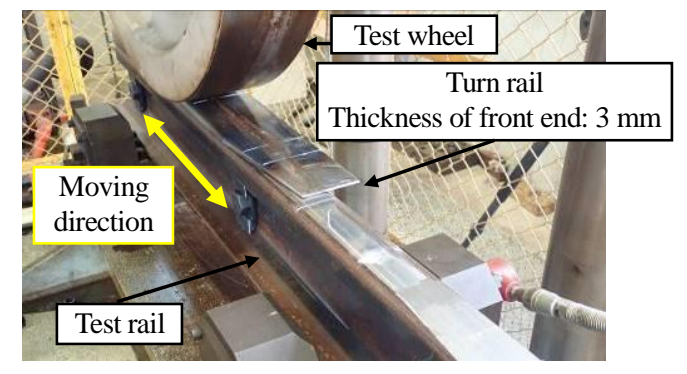

Table 3 Rolling fatigue test conditions.

\begin{tabular}{c|c}
\hline Item & Conditions \\
\hline Specimen & $\begin{array}{c}\text { Front end of turn rail } \\
\text { (Thickness: } 3 \mathrm{~mm} \text { ) }\end{array}$ \\
\hline Vertical load & $83 \mathrm{kN}$ (Static), $143 \mathrm{kN}$ (Dyanamic) \\
\hline Range of movement & $\pm 250 \mathrm{~mm}$ \\
\hline Moving speeds & 5 sec. $/$ cycle \\
\hline Target cycles & 60,000 cycles \\
\hline
\end{tabular}

Fig.7 Rolling fatigue test apparatus.

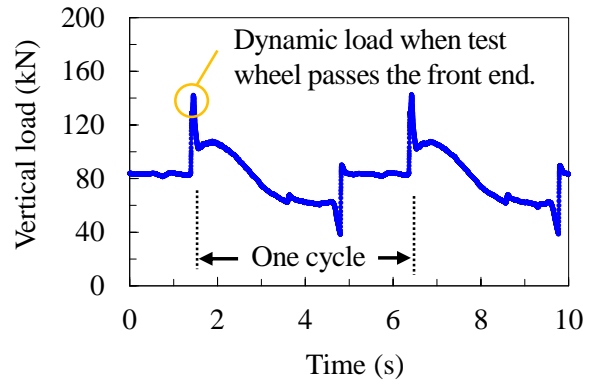

Fig.8 Vertical load of the test. The maximum value of the load is based on the FEM analysis.

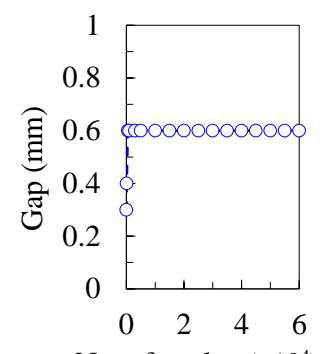

No. of cycles $\left(\times 10^{4}\right)$

(a) Gap

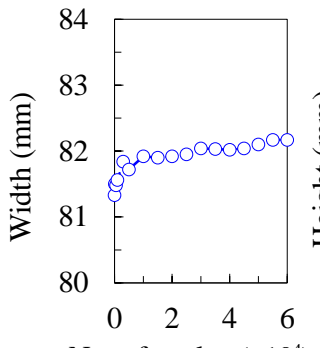

No. of cycles $\left(\times 10^{4}\right)$

(b) Width

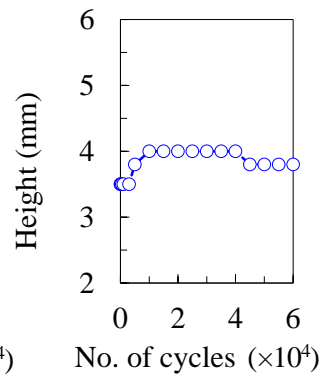

(c) Height

Fig.9 No. of cycles and shape changes of the front end of turn rail. The remarkable changes are not observed. 
図 9 に載荷回数と転換レールの先端部の隙間, 先端部の幅および先端部の試験レールから高さの関係を示す. また，図 10 に 6 万回載荷後の試験体の外観を示す.転換レールの先端部の隙間は，載荷回数 500 回程度の載荷初 期に $0.4 \mathrm{~mm}$ 程度まで増加しているものの, その後は安定して推移している. また，先端部の幅と高さについて も大きな変化は認められず，6万回の載荷後の外観についても損傷は認められない. このため, 目標厚さ $3 \mathrm{~mm}$ で設計した転換レールの先端部は，年間の軸重の合計が $1.0 \times 10^{8} \mathrm{kN}$ の線区で 1 力月間敷設する条件において，十 分な耐久性を有することを確認した。

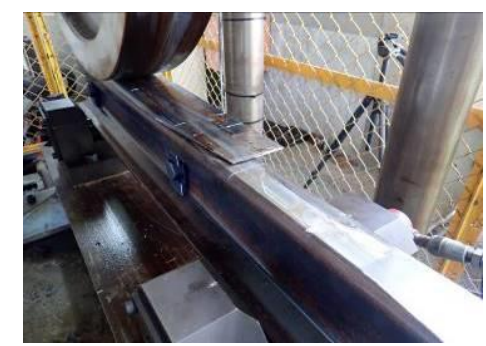

(a) Whole specimen

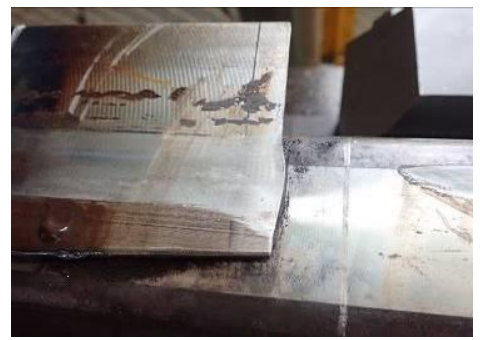

(b) Focus on the front end

Fig.10 Appearance of the specimen after 60,000 cycles. The crack and deformation such as a conspicuous warp is not observed after the test. The durability of the front end with a thickness of $3 \mathrm{~mm}$ is verified under the condition that the design use period is one month and the total annual axle load is $1.0 \times 10^{8} \mathrm{kN}$.

\section{3. 最終設計と製作}

前章に示した事前検討の結果を踏まえ, 提案する構造の最終設計と製作を行った. 図 11 に最終設計時の構造を 示す．本構造は，主にポイント部とクロッシング部に分かれ，転換レール，支持レール，分岐レール，ガードレ 一ル，分岐まくらぎ，床板およびレール締結用座金により構成される．ポイント部とクロッシング部の転換レー ルが既設レール，支持レールおよび分岐レール上に被さることで，単線並列運転用の分岐構造となる.

初期設計時からの主な変更点は，す心゙ての既設まくらぎを分岐まくらぎに交換し，2.3 節の検討結果を踏まえ， 転換レールを計 5 箇所（片側レール分）で固定したうえ，転換レールの先端部を分割し，万一損傷が生じた際の 交換を容易にした点である．既設の軌道に本構造を設置する際には，既設レール以外の上記部材をすべて交換・ 新設する必要がある。ただし，敷設時に既設レールの切断は不要である。また，転換前の状態では，軌道の弱点 箇所となり得る軌道の欠線部がないのに加え, レール間の車輪の乗り移り箇所がないため, 既存の分岐器では必 須となる既設線側の軌道材料の検査（分岐器の一般検査，細密検査，機能検査）（佐藤，1987）が省略できる.

ここで，本構造上の主な特徴は以下のとおりである.

ポイント部の転換レールの先端部は, 図 12(a)に示すように本体から切り離して別部材とし, 損傷した際の交換 を容易にした。 また, 先端部の厚さは, 当初の目標值である $3 \mathrm{~mm}$ とした。一方, ポイント部の転換レールの後 端部は，図 12(b)に示すように分岐レールの頭部を切削加工することで段差を $0 \mathrm{~mm}$ とした.クロッシング部の転 換レールの先端部と後端部も図 12(b)と同様に分岐レールを切削加工することで段差を $0 \mathrm{~mm} と$ と . 転換レール の頭部の高さは，ポイント部とクロッシング部ともに図 12(c)に示すように $45 \mathrm{~mm}$ とた。.これにより，技術基 準(土木関係技術基準調査研究会編，2014)で規定された車両と軌道の接触防止のための離隔を確保した. 図 13 に 分岐線側のレール頭頂面高さとレール長手方向距離の関係を示す. ポイント部とクロッシング部のレール頭頂面 高さの最大值は, 分岐構造に進入する前の一般区間の高さを $0 \mathrm{~mm}$ とした場合, 車両との接触防止のための離隔 $45 \mathrm{~mm}$ に転換レールの板厚 $12 \mathrm{~mm}$ を加えた $57 \mathrm{~mm}$ となる. 本構造上の高低差を営業列車が通過する際の走行安全

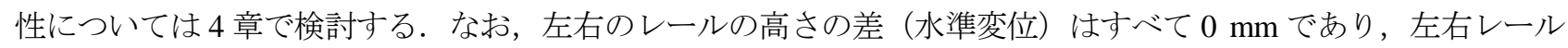
に構造上のねじれ（平面性変位）はない. 


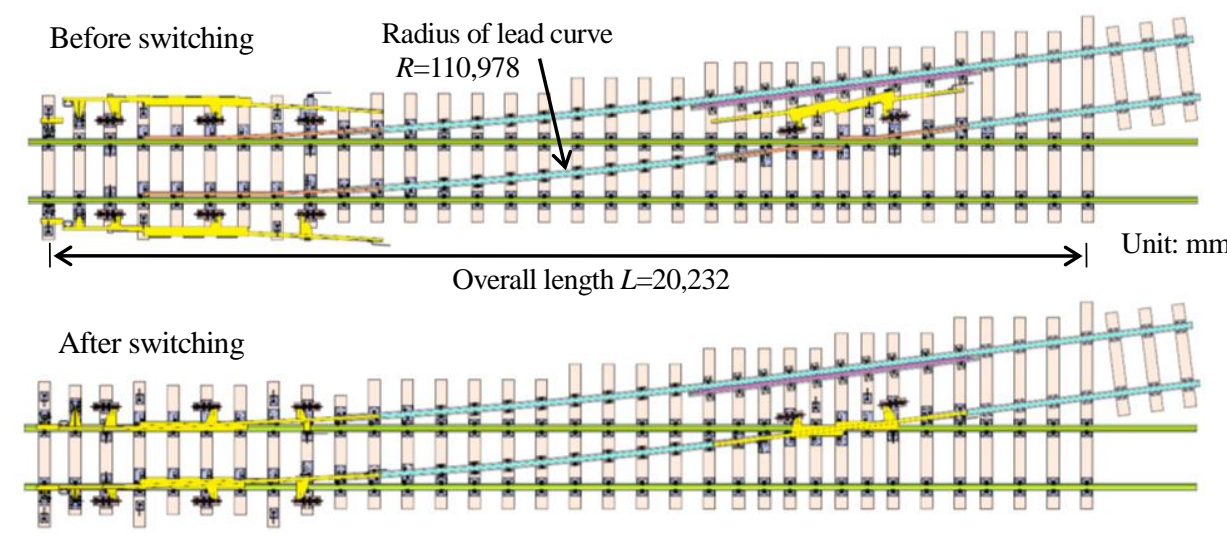

(a) Overview of the structure

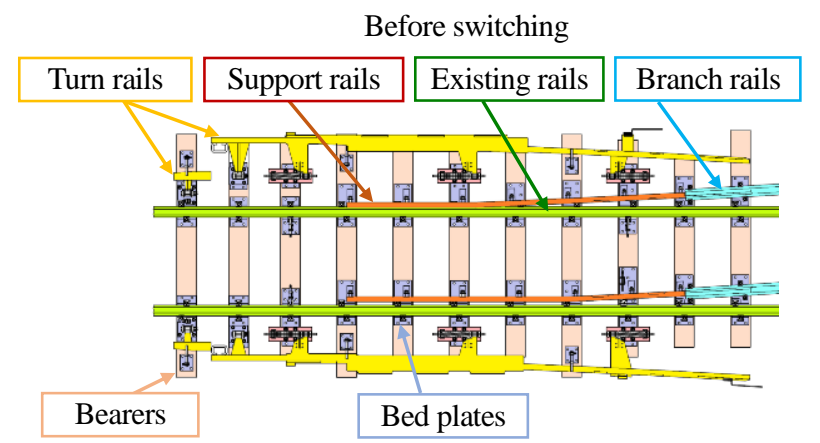

After switching

(b) Switch panel of the structure

Before switching

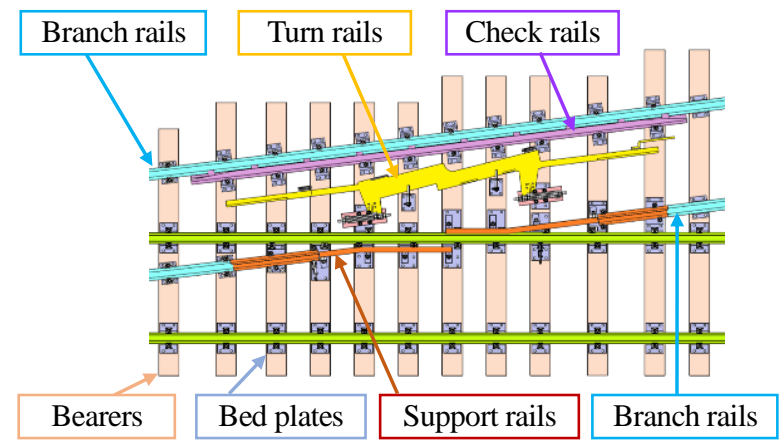

After switching

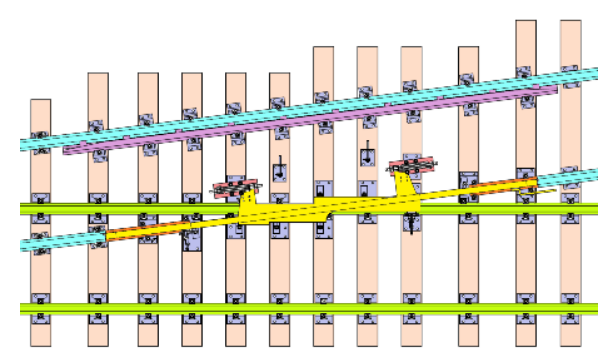

(c) Crossing panel of the structure

Fig.11 Proposed structure of a switch and crossing at a final design stage. The proposed structure consists of the turn rails, support rails, branch rails, check rails, bearers, bed plates and rail fastenings.

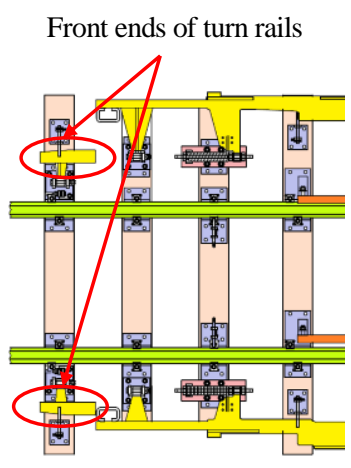

(a) Front ends of turn rails

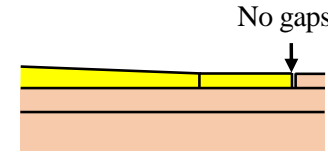

(b) Rear ends of turn rails

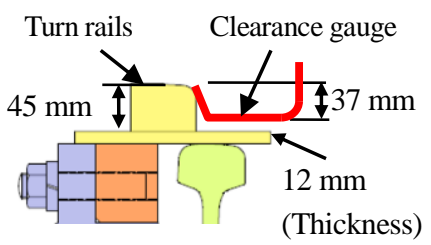

(c) Height of turn rails

Fig.12 Front and rear ends of turn rails. 
最終設計に基づき，提案する分岐構造を製作し，(公財）鉄道総合技術研究所の日野土木実験所の試験用軌道に 敷設した. 図 14 に製作した分岐構造の外観を示寸. 敷設工事は, 既設の軌道部材の撤去から新設と軌道整備を含 めて計 4 日間で行い，施工上の問題がないことを確認した.

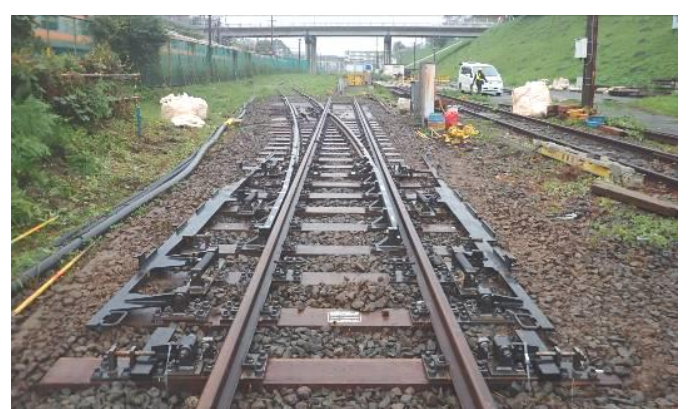

(a) Overview of the structure (before switching)

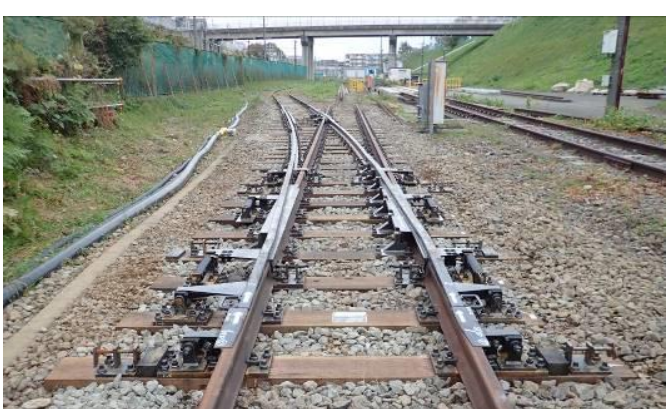

(b) Overview of the structure (after switching)

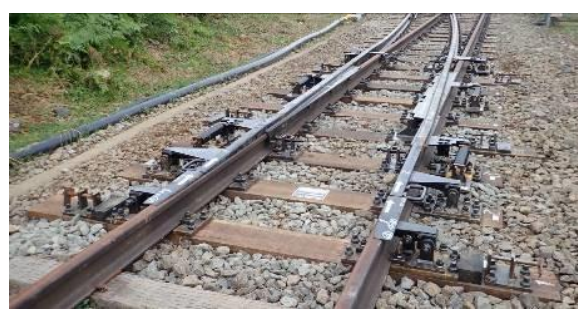

(c) Switch panel

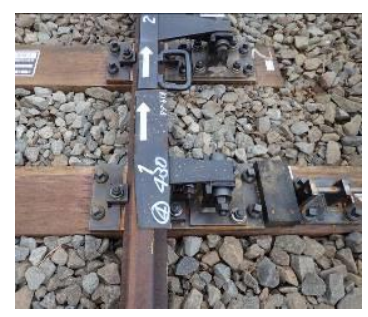

(d) Front end of turn rails

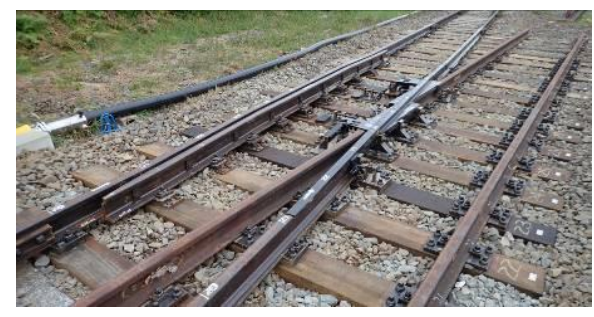

(e) Crossing panel

Fig.14 Product of the structure installed at the test track. The construction period is 4 days, which period is spent for removing the exising structure, establishing the proposed structure and track maintenance.

\section{4. 走行安全性と部材強度の確認}

本章では, 試験用軌道に敷設した分岐構造上にモータカーを走行させる試験を行うとともに, 本走行試験と営 業列車の走行を模擬した走行解析を行うことで，提案した構造の走行安全性と部材強度の評価を行った．また， 走行解析では評価が困難な詳細部位の強度を確認するため，室内載荷試験を行った．

\section{$4 \cdot 1$ モータカーの走行試験}

ここでは，分岐線側を開通させた状態でモータカーを走行させ，輪重と横圧および転換レールに発生する応力 を測定した. 本試験に使用したモータカーは，2つの輪軸が軸距 $3.5 \mathrm{~m}$ で直接車体に連結する構造を有する. 図 15 に走行試験の状況を示す. モータカーの走行方向は対向と背向とし, 走行速度は $5 \mathrm{~km} / \mathrm{h}, 10 \mathrm{~km} / \mathrm{h}, 15 \mathrm{~km} / \mathrm{h}$ と した. 図 16 に輪重，横圧と応力の測定位置を示寸．輪重と横圧は，1 箇所につき計 4 枚のクロスゲージをそれぞ

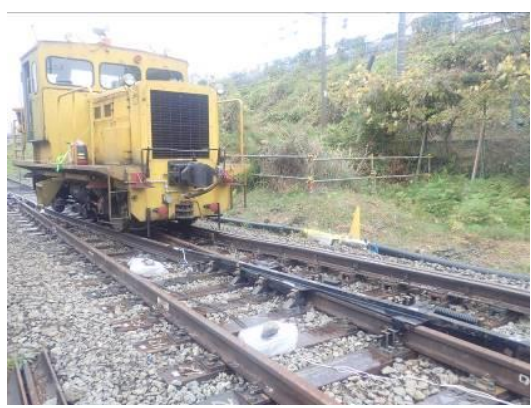

Fig.15 Running tests of the motor car.

\section{\begin{tabular}{|llll}
\hline Wheel loads 0 & Lateral loads & Stress of turn rails & $\boldsymbol{\Delta}$ \\
\hline
\end{tabular}}

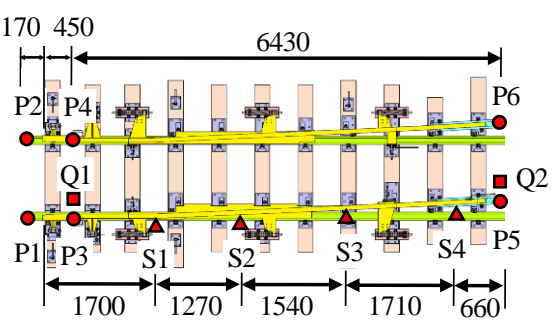

(a) Switch panel

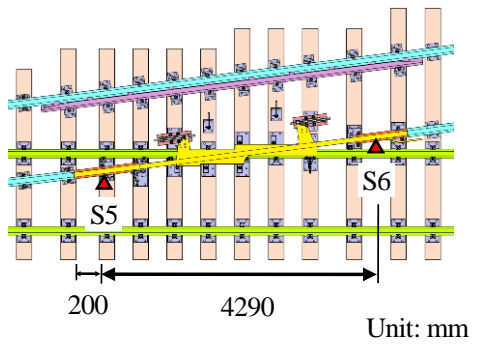

(b) Crossing panel
Fig.16 Measuring points of wheel loads lateral loads and stress of turn rails. 
れレールの腹部と底部に貼り付け，せん断ひずみ法 (加藤, 矢澤，1999）により測定した. なお，輪重と横圧は， 既設レールと分岐レールに作用する值を測定したものであり，モータカーが転換レールを乗り降りする際の挙動 が荷重に及ぼす影響を調べるために測定している．また，応力は，輪重と横圧による曲げ変形を想定し，外軌側 の転換レールの頭部側面にロゼットゲージを貼り付け, Mises 応力として整理した.

本走行試験の結果, 対向・背向走行ともに, 目標とした最高速度 $15 \mathrm{~km} / \mathrm{h}$ において, 実車両が通過可能なこと を確認した. 図 17 に走行試験の各ケースで得られた輪重, 横圧と応力の最大值を示す. 輪重の最大值は, 背向時 の測点 $\mathrm{P} 1 ， \mathrm{P} 2$ において $44 \mathrm{kN} \sim 57 \mathrm{kN}$ 程度であり, 対向時および他の測点と比較して大きい傾向を示した. これ は，車輪がポイント部の転換レールの先端部の段差を降りた際の衝撃の影響であると考えられる．横圧の最大值 は，対向時の測点 $\mathrm{Q} 2$ において $9 \mathrm{kN} \sim 11 \mathrm{kN}$ 程度であり，背向時および測点 $\mathrm{Q} 1$ と比較して大きい．これは．転換 レールから分岐レールに乗り移った際の影響であると考えられる. 転換レールの応力の最大值は, ポイント部 (S1 ～S4）において $15 \mathrm{~N} / \mathrm{mm}^{2} \sim 60 \mathrm{~N} / \mathrm{mm}^{2}$ 程度, クロッシング部において $34 \mathrm{~N} / \mathrm{mm}^{2} \sim 88 \mathrm{~N} / \mathrm{mm}^{2}$ 程度であり, 測定位置 により值は異なるものの, 走行方向および走行速度の違いによる顕著な差は認められなかった. 本走行試験にお ける転換レールの発生応力は, S45C 材の降伏応力（490 N/ $\mathrm{mm}^{2}$ 以上）と比較して十分に小さいことを確認した.

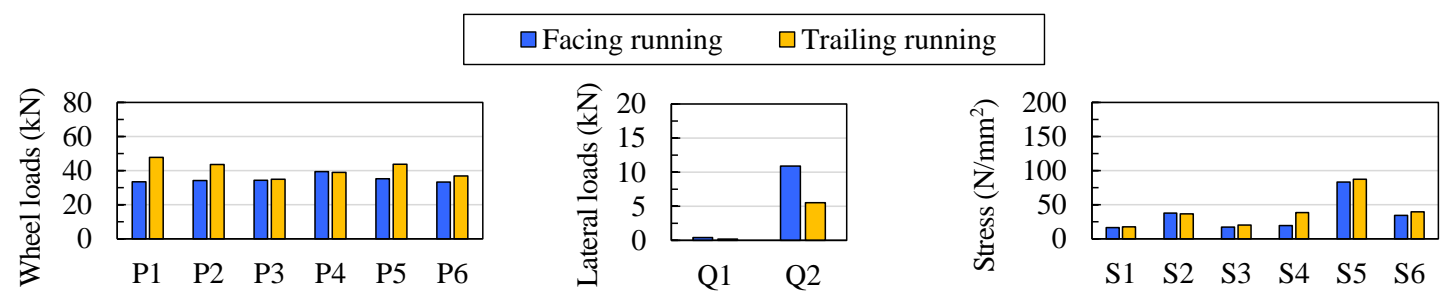

(a) Wheel loads, lateral loads and stress at speed $5 \mathrm{~km} / \mathrm{h}$
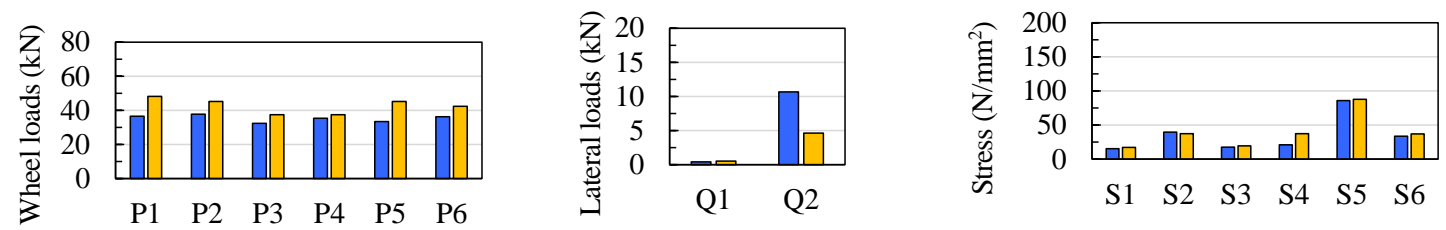

(b) Wheel loads, lateral loads and stress at speed $10 \mathrm{~km} / \mathrm{h}$
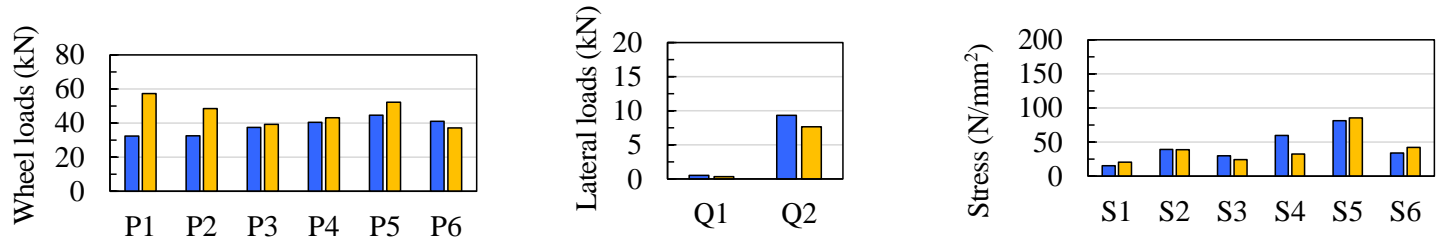

(c) Wheel loads, lateral loads and stress at speed $15 \mathrm{~km} / \mathrm{h}$

Fig.17 Maximum wheel loads, lateral loads and stress obtained from the running tests. The maximum values of stress measured at turn rails are smaller than yield stress of the material $\left(490 \mathrm{~N} / \mathrm{mm}^{2}\right)$.

\section{$4 \cdot 2$ モータカーの走行解析}

前節に示したモータカーの走行試験を模擬した走行解析を行い，解析モデルの妥当性を検証した．走行解析手 法と解析ソルバーは 2.2 節と同じである. 図 18 に最終設計時の分岐構造の解析モデルを示す. 軌道の各ばね定数 は表 2(a) と同じである．モータカーの車両諸元は，表 4 に示寸とおりである．モータカーの軸重は，前節の試験 時に，クロスゲージを貼付したレール上にモータカーを静止させることで実測した值を用いた．走行方向は対向 と背向とし，走行速度は $15 \mathrm{~km} / \mathrm{h}$ とした。

図 19 に走行解析と走行試験で得られた転換レールの発生応力の最大值を示寸. 走行解析における発生応力は, 走行試験の測点 S1〜S4 の位置に対応するソリッド要素の Mises 応力としている. 図 19 より, 解析結果は, 試験 結果と比較して一部の測点で $30 \mathrm{~N} / \mathrm{mm}^{2}$ 程度の差が見られるものの, 各測点の応力の傾向を概ね捉えている. 


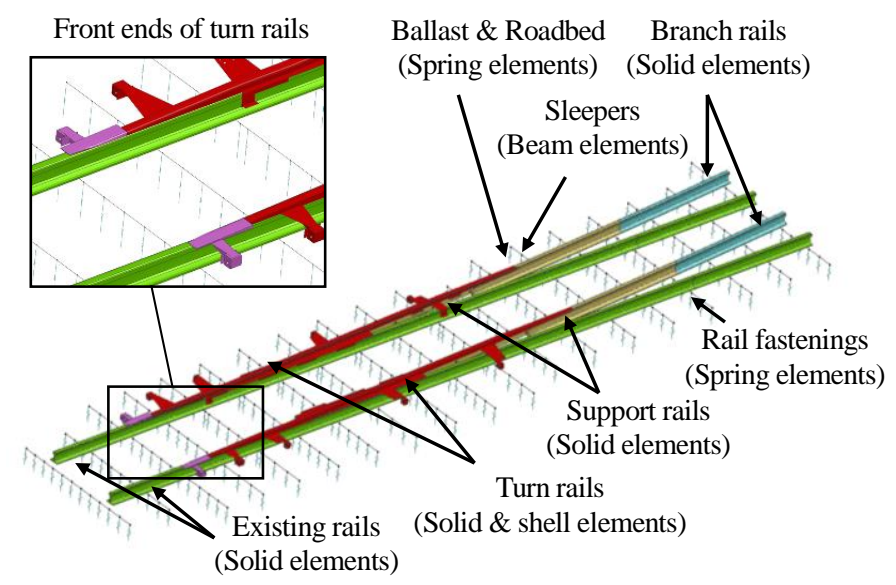

Table 4 Main parameters of the motor car model.

\begin{tabular}{c|c}
\hline Item & Values \\
\hline Total number of wheelsets & 2 \\
\hline Wheelbase & $3.5 \mathrm{~m}$ \\
\hline Axle springs & $0.844 \mathrm{kN} / \mathrm{mm}$ \\
\hline $\begin{array}{c}\text { Coefficient of friction } \\
\text { between rail and wheel }\end{array}$ & 0.3 \\
\hline Suspended mass & $1.064 \times 10^{4} \mathrm{~kg} / \mathrm{car}$ \\
\hline Unsuspended mass & $1.175 \times 10^{3} \mathrm{~kg} / \mathrm{axel}$ \\
\hline Axle loads & $63.65 \mathrm{kN}$ \\
\hline
\end{tabular}

Fig.18 FEM model of the proposed structures at a final design stage.

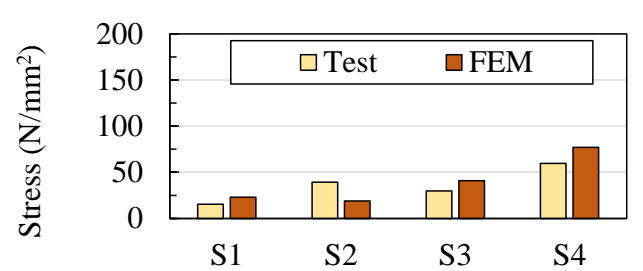

(a) Facing run

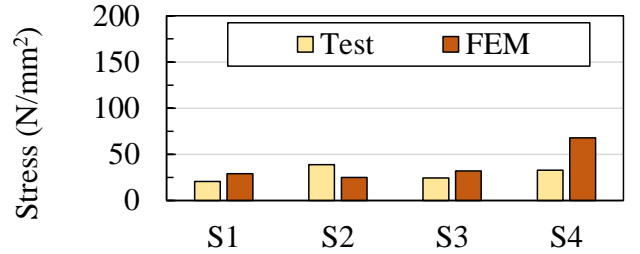

(b) Trailing run

Fig.19 Von Mises stress of the turn rails obtained from FEM and the running test. The FEM results are substantially coincident with the measurements of the running test of the motor car. The validity of the FEM model is confirmed.

\section{$4 \cdot 3$ 営業列車の走行解析}

提案した分岐構造の走行安全性を確認するため, 営業列車の走行解析を行った. 走行解析手法と解析ソルバー は，2.2 節と同じであり，分岐構造の解析モデルは図 18 と同じである.また，車両モデルは図 4 と同じとした. 車両の諸元は，表 2(b)に示す軸重 $150 \mathrm{kN}$ のケース（Case A）に加え，車体の重量のみを想定し，表 2(b)のばね上 質量（Suspended mass）を $2.16 \times 10^{4} \mathrm{~kg}$ として軸重を $77 \mathrm{kN}$ に低減したケース（Case B）を設定した.いずれも走 行方向は対向と背向とし, 走行速度は $15 \mathrm{~km} / \mathrm{h}$ とした. 図 20 に軸重の大きいCase A で得られた各部材の Mises 応力の最大值をコンター図で示す．部材の応力は， $3 \mathrm{~mm}$ の段差を有する転換レールの先端で $500 \mathrm{~N} / \mathrm{mm}^{2}$ 以上の 大きい值がみられるものの，これ以外の箇所においては，転換レールの側面で最大 $200 \mathrm{~N} / \mathrm{mm}^{2}$ 程度であり，部材

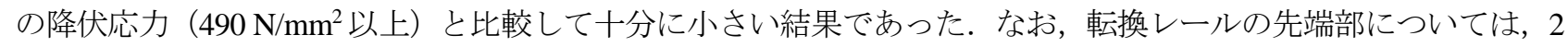

$$
\begin{array}{llllllllllll}
0 & 20 & 40 & 60 & 80 & 100 & 120 & 140 & 160 & 180 & 200 & \left(\mathrm{~N} / \mathrm{mm}^{2}\right)
\end{array}
$$

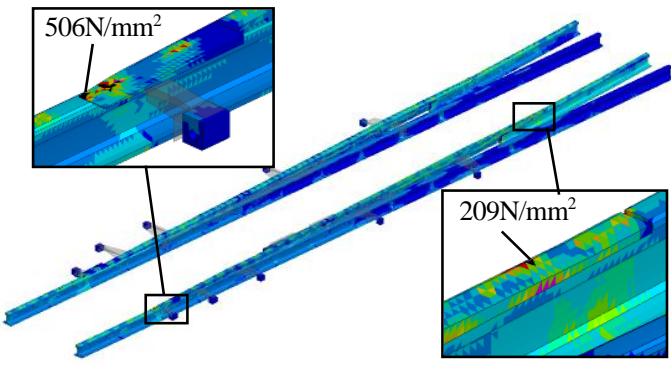

(a) Facing run

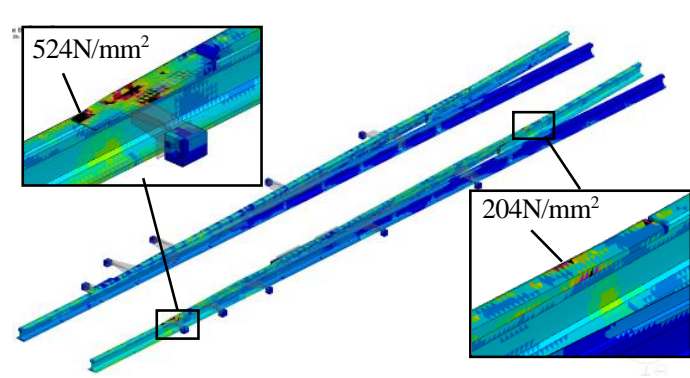

(b) Trailing run

Fig.20 Maximum von Mises stress of the model (Case A). The maximum value except for front end of the turn rail is about $200 \mathrm{~N} / \mathrm{mm}^{2}$ and is smaller than yield stress of the material $\left(490 \mathrm{~N} / \mathrm{mm}^{2}\right)$. 
Tamagawa, Shimizu, Mihara and Oikawa, Transactions of the JSME (in Japanese), Vol.86, No.886 (2020)

章に示したように，目標とした使用条件下において，列車の繰返し走行に対する而久性に問題がないことを確認 している.

図 21 に Case A で得られた外軌側の転換レールの先端部と後端部における軌間外側への水平変位の時刻歴応答 を示す. 転換レールの水平変位の最大值は, 先端部で背向時に $1.8 \mathrm{~mm}$, 後端部で対向時に $3.2 \mathrm{~mm}$ であり, 図 5 に示した初期設計時の水平変位と比較して十分に小さく，転換レールの固定箇所数を初期設計時の 2 箇所から 5 箇所に増加させた効果が確認できる. なお, Case B の各部材の応力と転換レールの水平変位は, Case A よりも小 さい結果であった.

次に, 脱線係数と輪重減少率の観点から走行安全性の評価を行った. 図 22 と図 23 に Case A と Case B の外軌 側の輪重 $P$, 横圧 $Q$ と脱線係数 $Q / P$ の解析結果を示す. 本結果に対する走行安全性の評価は, 在来線車両が低速 で急曲線を走行する際の判定指標（鉄道総合技術研究所，1993），(石田，2005）に則り，図 24 に示すフローで行 った，なお，図中の脱線係数とは，横圧を輪重で除した值であり，脱線に対する走行安全性の評価指標として一 般的に用いられるものである. また，輪重減少率とは，静止時の輪重（軸重の半分）から輪重を引き，これを静

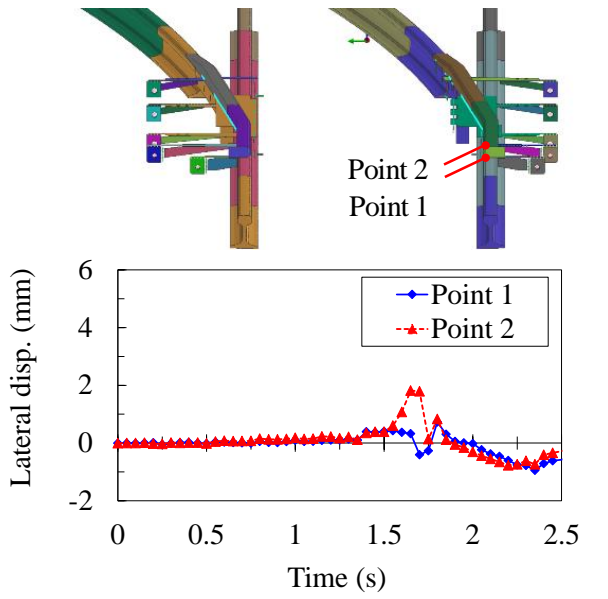

(a) Displacement of the front end (trailing run)

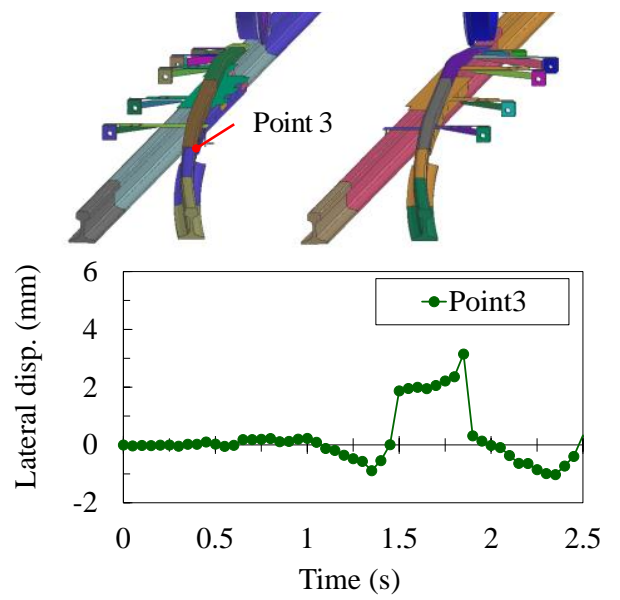

(b) Displacement of the rear end (facing run)

Fig.21 Relationship between times and lateral displacements of the front and rear end of the structure (Case A). The maximum displacement of the front end is $1.8 \mathrm{~mm}$ and rear end is $3.2 \mathrm{~mm}$. These values are smaller than that of an initial design stage as described in Fig.5. The effects of the increase in the number of the connections between turn rails and sleepers are confirmed.

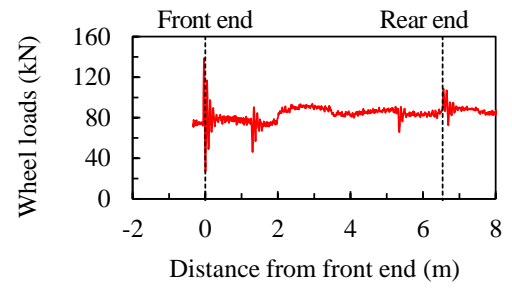

(a) Wheel loads $P$ (facing run)

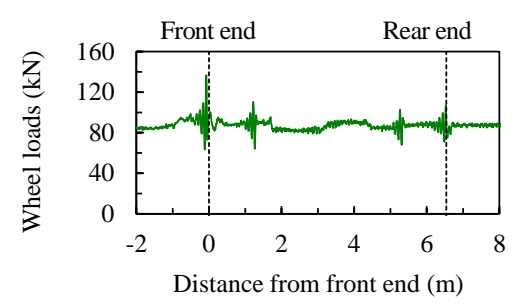

(d) Wheel loads $P$ (trailing run)

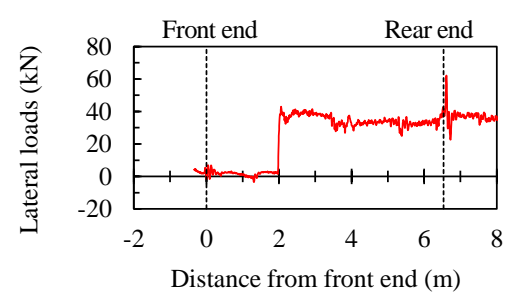

(b) Lateral loads $Q$ (facing run)

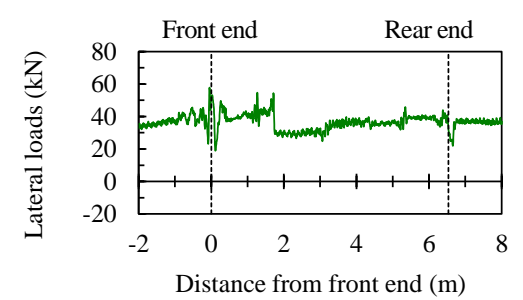

(e) Lateral loads $Q$ (trailing run)

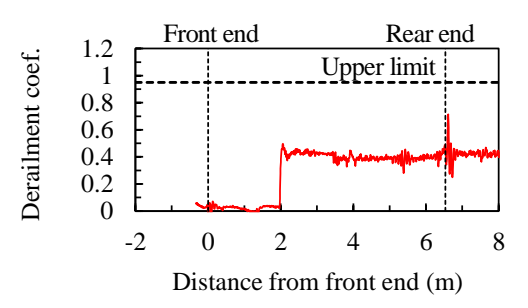

(c) Derailment coefficient $Q / P$ (facing run)

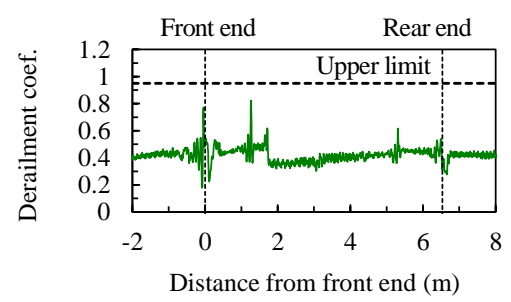

Fig.22 Wheel loads, lateral loads and derailment coefficient (Case A). The derailment coefficients are all within the upper limit. 


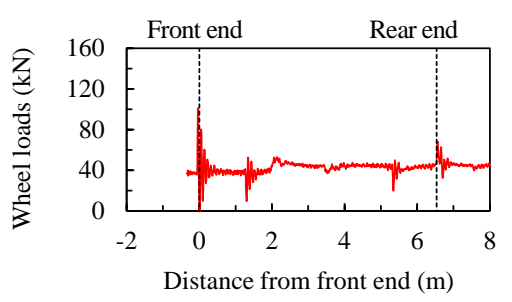

(a) Wheel loads $P$ (facing run)

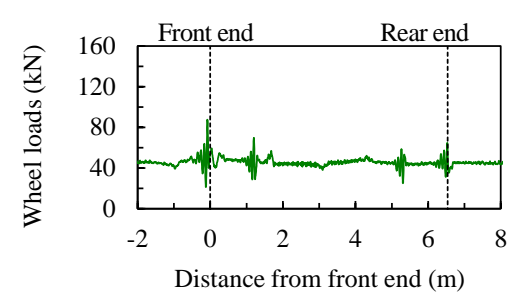

(d) Wheel loads $P$ (trailing run)

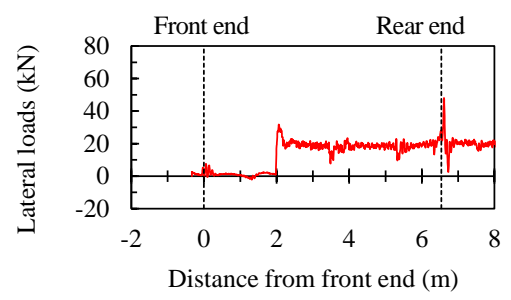

(b) Lateral loads $Q$ (facing run)

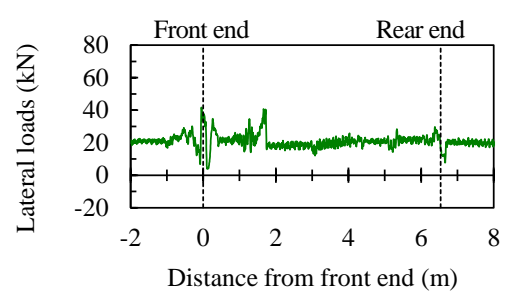

(e) Lateral loads $Q$ (trailing run)

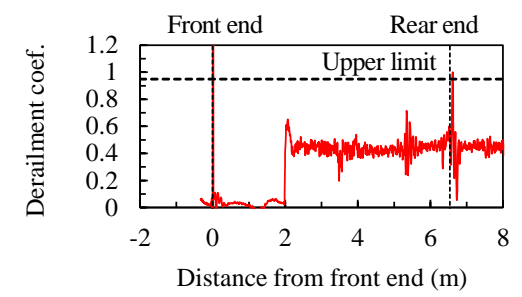

(c) Derailment coefficient $Q / P$ (facing run)

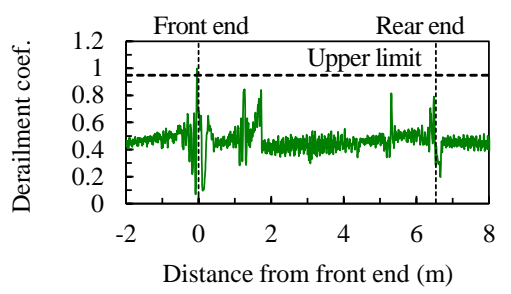

(f) Derailment coefficient $Q / P$ (trailing run)

Fig.23 Wheel loads, lateral loads and derailment coefficient (Case B). The derailment coefficients are exceeding the upper limit at front and rear end of turn rails.

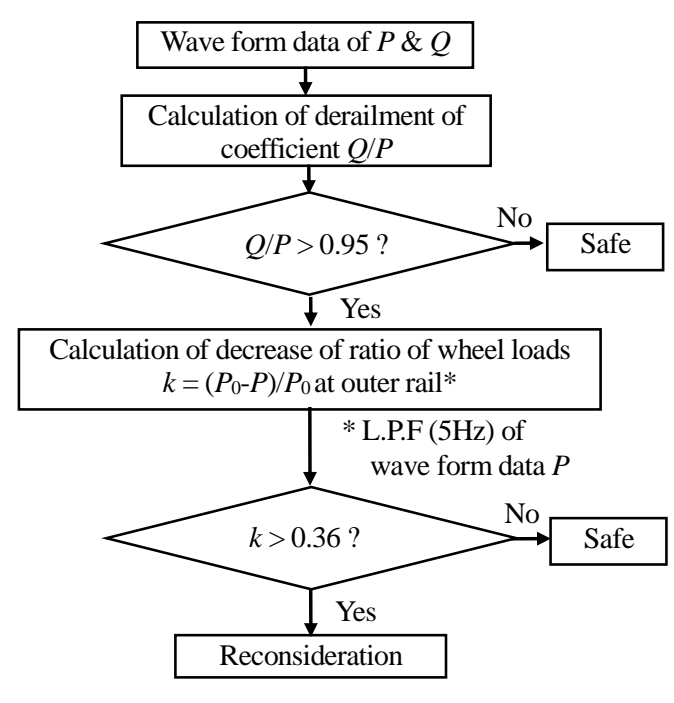

Fig.24 Flow chart for the evaluation of a running safety.

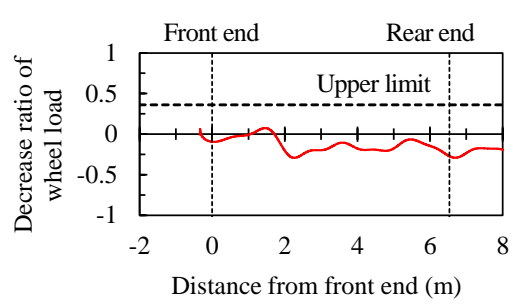

(a) Facing run

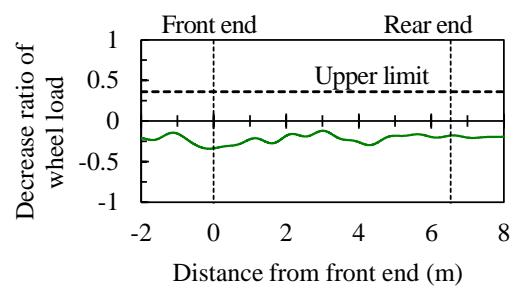

(b) Trailing run

Fig.25 Decrease of ratio of wheel loads $k$ (Case B). The ratio is all within the upper limit.

止時の輪重で除して算定したものであり，脱線係数と併用し，走行安全性の補助的な評価指標として用いられる ものである．なお，輪重減少率の算定時の輪重には $5 \mathrm{~Hz}$ のローパスフィルタ処理をしている．また，輪重減少率 の目安值 $k_{L}$ は, 文献（石田，2005）に基づき，提案した分岐構造の最小曲線半径 $R=110.978 \mathrm{~m}$ から次式で算定し た值である。

$$
k_{L}=0.0021 \times R+0.13 \quad(R<225 \mathrm{~m})
$$

図 22 と図 23 より, 輪重は Case A の転換レールの先端部で大きく, 対向時で最大 $139 \mathrm{kN}$, 背向時で最大 $137 \mathrm{kN}$ であった．また，横圧は，Case Aの対向時において転換レールの後端部で最大 $62 \mathrm{kN}$ ，背向時において転換レー ルの後端部で最大 $58 \mathrm{kN}$ であった. 脱線係数は, Case B の転換レールの先端部と後端部で大きく, 図 24 に示す 脱線係数の目安值 0.95 を超過している. そこで, Case B の脱線係数が 0.95 を超過した箇所について, 輪重減少 率を計算した. 図 25 に外軌側の輪重減少率を示寸. 図 25 より, 脱線係数が目安值を超過した箇所の輪重減少率 は, 対向時, 背向時ともに輪重減少率の目安值 0.36 以内に収まっている. 
以上の結果より，部材応力と転換レールの変位および脱線係数と輪重減少率の観点から，本解析で想定した営 業車両に対して，走行安全性に問題はないことを確認した.

\section{4-4 室内載荷試験}

本節では，走行解析では評価が困難な転換レールや床板の溶接部，転換用のばね部，座金やボルトなどの詳細 部位の疲労強度を確認するため, 室内載荷試験を行った. 本試験では, 図 26 に示すように提案した分岐構造のう ち，外軌側のまくらぎ 3 本分の軌きょうを実物大で製作したものを試験体とした．当該箇所は，上記の詳細部位 をすべて含んだ代表箇所である。なお，既設レールは，本試験において荷重を負担しないため省略している。

ここでは，鉄道構造物等設計標準・軌道構造（鉄道総合技術研究所，2012）の軌道部材の設計作用を参考とし， 軸重 $150 \mathrm{kN}$ を 2 で除して静止時の輪重とし, これに変動輪重係数と変動横圧係数を乗じて輪重と横圧を算定した

(表 5). 提案する分岐構造のような急曲線において台車の前方と後方の車輪が通過する際には，それぞれレール を軌間の外側と内側一傾かせる横圧が発生する場合がある(Deshimaru et al., 2017). そこで本試験では，試験体中 央の転換レールの頭部に対して，軌間の内側と外側からそれぞれ輪重と横圧の合力を想定した試験荷重 $L_{A}$ と $L_{B}$ を交互に繰返し載荷した. 図 27 に室内載荷試験の状況を, 表 6 に試験条件を示す. 試験荷重の最小值 $L_{A m i n} と L_{B m i n}$ は，試験時の安定性を考慮して $10 \mathrm{kN}$ とした。そこで，試験荷重の最大值 $L_{A \max }$ と $L_{B \max }$ および試験角度 $\theta_{A}$ と $\theta_{B}$ は，試験時の鉛直方向と水平方向の合力が表 5 の輪重と横圧に一致するように設定した.

目標繰返し回数は, 試験荷重の最大值 $L_{A \max }$ と $L_{B \max }$ をそれぞれ 200 万回とし, 計 400 万回の車輪通過回数を想 定した．本試験では，載荷点直下における転換レールの頭部と床板の水平方向変位を測定するとともに，載荷中 と試験終了後における各部の状態を外観観察した。

図 28 に載荷回数と転換レールの頭部および床板の水平方向変位の関係を示す. 水平方向変位は, 転換レールの 頭部, 床板ともに安定して推移しており，400 万回の目標載荷回数を達成した. なお，本困の 200 万回時点でグ ラフに不連続箘所があるのは，200 万回の時点で一度試験機を停止し，除荷したうえで外観観察を行ったためで ある.なお，外観観察後，ボルトの締め直しなどは行わず，試験を再開した．図 29 に 400 万回載荷後の各部の状 態を示す. 外観観察の結果，転換レールと支持レールの間に摺動した跡が確認されたまた，転換用ばねのシャ フトに $40 \mathrm{~mm}$ 程度の移動が確認された. ただし, 転換レールや支持レール, 床板や座金, 転換用ばねのシャフト

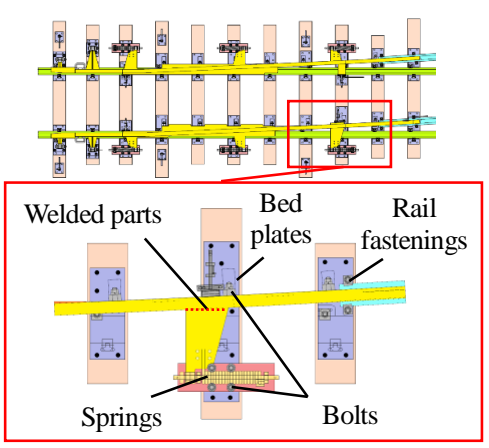

Fig.26 Specimen for the loading test.
Table 5 Wheel loads and Lateral loads.

\begin{tabular}{c|c|c}
\hline Load & Gauge corner & Field corner \\
\hline $\begin{array}{c}\text { Wheel } \\
\text { loads }\end{array}$ & $\begin{array}{c}75 \mathrm{kN} \times 1.3 \\
=98 \mathrm{kN}\end{array}$ & $\begin{array}{c}75 \mathrm{kN} \times 1.15 \\
=86 \mathrm{kN}\end{array}$ \\
\hline $\begin{array}{c}\text { Lateral } \\
\text { loads }\end{array}$ & $\begin{array}{c}75 \mathrm{kN} \times 0.8 \\
=60 \mathrm{kN}\end{array}$ & $\begin{array}{c}75 \mathrm{kN} \times 0.4 \\
=30 \mathrm{kN}\end{array}$ \\
\hline
\end{tabular}

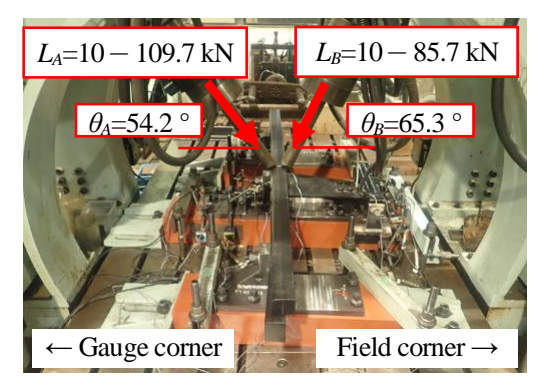

Fig.27 Loading test arrangement.

Table 6 Loading test conditions.

\begin{tabular}{c|c|c}
\hline Item & Unit & Conditions \\
\hline Test loads & $\mathrm{kN}$ & $L_{A}: 10-109.7 \mathrm{kN}\left(\theta_{A}=54.2^{\circ}\right)$ \\
\cline { 3 - 3 } & $L_{B}: 10-85.7 \mathrm{kN}\left(\theta_{B}=65.3^{\circ}\right)$ \\
\hline $\begin{array}{c}\text { Wave form } \\
\text { of loads }\end{array}$ & - & $\begin{array}{c}\text { Sin wave } \\
\text { Phase difference between } L_{A} \text { and } L_{B}: 180^{\circ}\end{array}$ \\
\hline $\begin{array}{c}\text { Loading } \\
\text { frequency }\end{array}$ & $\mathrm{Hz}$ & 5.5 \\
\hline $\begin{array}{c}\text { Target of total } \\
\text { no. of loadings }\end{array}$ & Times & $\begin{array}{c}4,000,000 \\
L_{A}: 2,000,000 \text { and } L_{B}: 2,000,000\end{array}$ \\
\hline
\end{tabular}

Fig.28 Displacements of the turn rail and the bed plate. The values are stable. 


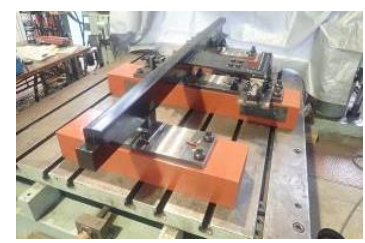

(a) Overview of the specimen

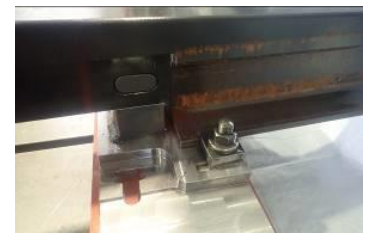

(e) Rail fastenings

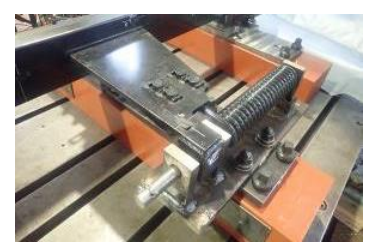

(b) Turn rail and spring

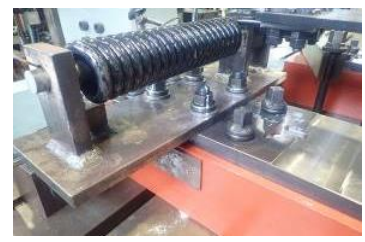

(f) Bolts and screw spikes

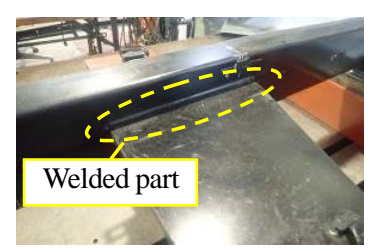

(c) Welded part of the turn rail

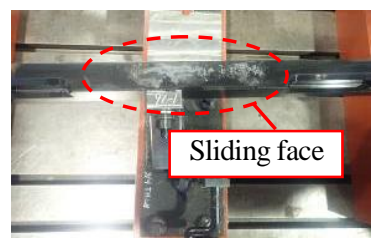

(g) Sliding face of support rail

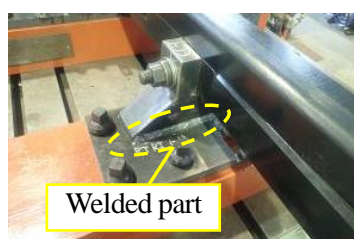

(d) Welded part of bed plates

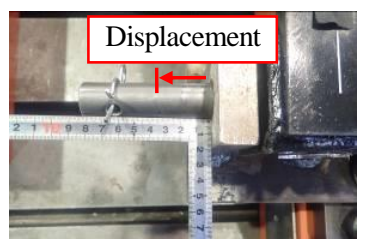

(h) Displacement of shaft

Fig.29 Appearance of the specimen after 4,000,000 times loading. The loading is finished without causing problems on strength of each parts.

に変形は生じておらず，試験前と同様に転換が可能なことを確認した．また，転換レールや床板の溶接部，転換 用のばねにき裂は認められなかった。さらに，各部のボルトの緩みもみられず，本条件における強度上の問題は 認められなかった.

ここで，提案した分岐構造は，年間に通過する車両の軸重の合計が $1.0 \times 10^{8} \mathrm{kN}$ の線区で 1 力月間程度の連続 使用を想定している.これを使用回数 1 回とすると，軸重 $150 \mathrm{kN}$ で約 6 万回の車輪通過回数となるため, 上記の 試験における 400 万回の載荷回数は，65 回以上の使用回数に相当する. 本構造の使用周期については設定してい ないものの，仮に年間 1 2 回の使用を想定した場合， 30 年〜 60 年以上の耐久性が保証できる. また，本試験で 考慮した輪重と横圧は，実軌道においてごく稀に発生することを想定した変動係数を乗じたものであるため，実 際には上記を上回る耐久性が期待できる。

以上より，転換レールや床板の溶接部，転換用のばね部，座金やボルト類について，実用上十分な強度を有す ることを確認した.

\section{5. 結 言}

本研究では，単線並列運転を軌道側から支援する技術として，工事区間の前後に設置できる新しい分岐構造を 設計・製作するとともに，その走行安全性と部材強度を評価した。

主な結果は以下のとおりである.

(1) 営業列車の通過を前提としたうえで, 既設レールの切断をせずに設置可能で, 必要時に単線並列運転に切 り替え可能な分岐構造を設計・製作した。

(2) 転換レールの先端部を模擬した試験体の転動疲労試験を行い，3 $\mathrm{mm}$ の段差を有する先端部は, 目標とした 年間に通過する車両の軸重の合計が $1.0 \times 10^{8} \mathrm{kN}$ の線区で 1 ケ月間連続使用寸る条件において，十分な耐久 性を有することを確認した.

(3) 製作した分岐構造を試験用軌道に敷設し, 施工上の問題がないことを確認するとともに，モータカーの走 行試験を行い, 目標とした最高速度 $15 \mathrm{~km} / \mathrm{h}$ において実車両が通過可能なことを確認した.

(4) 営業列車の通過を想定した走行解析を行い, 部材の発生応力, 脱線係数および輪重減少率の観点から, 提 案した分岐構造は，営業列車の走行において安全上の問題がないことを確認した.

（5）提案した分岐構造の外軌側のまくらぎ 3 本分の軌きょうを試験体とする室内載荷試験を行い，走行解析で は評価が困難な転換レールや床板の溶接部，転換用のば部，座金やボルトについて，実用上十分な強度 を有することを確認した. 
謝辞

本研究では，提案した分岐構造を製作するにあたり，鉄道機器株式会社からの全面的な協力を得た．ご支援頂 いた皆様に感謝の意を表する.

\section{文献}

Deshimaru, T., Tamagawa, S. and Kataoka, H., A study on verification test method for rail fastening systems, Proceedings of the 14th international conference on railway engineering (2017).

土木関係技術基準調査研究会編, 鉄道に関する技術基準(土木編), 第三版 (2014), pp.212-256.

石田弘明, 急曲線低速走行試験における安全性評価手法, 鉄道総研報告, Vol.19, No.9 (2005), pp.5-10.

石野氏暁, 横取り装置, 新線路, Vol.70, No.10 (2016), pp.80-81.

加藤武, 矢澤英治, 輪重・横圧の地上測定, 新線路, Vol.53, No.11 (1999), pp.33-35.

西宮裕騎, 動的陽解法有限要素法を用いた鉄道車両の走行解析手法の構築，土木学会論文集 A2, Vol.74, No.2 (2018), pp.649-660.

及川祐也, 分岐器, RRR, Vol.73, No.9 (2016), pp.28-31.

鉄道総合技術研究所編, 在来鉄道運転速度向上試験マニュアル・解説 (1993), p.91.

鉄道総合技術研究所編，鉄道構造物等設計標準・同解説一軌道構造 (2012), pp.187-199.

佐藤泰生, 分岐器の構造と保守 (1987), pp.415-417, 日本鉄道施設協会.

Shimizu, S., Oikawa, Y. and Shiota, K., Construction of method for analytical evaluation of turnout structures, Quarterly Report of RTRI, Vol.60, No.4 (2019), pp.268-273.

杉山陽一, 岩田浩司，山本春生，運行管理と保安制御を融合した列車運転制御システムの基礎検討，鉄道総研報 告, Vol.32, No.5 (2018), pp.35-40.

富井規雄, 鉄道ダイヤのつくりかた (2012), p.23, オーム社.

柳川秀明，可動式横取り装置ができるまで, 新線路, Vol.74, No.1 (2020), pp.56-58.

\section{References}

Deshimaru, T., Tamagawa, S. and Kataoka, H., A study on verification test method for rail fastening systems, Proceedings of the 14th international conference on railway engineering (2017).

Investigating Committee of Technical Standard for Civil engeerings ed., Technical standard for railway-civil engineering, third edition (2014), pp.212-256 (in Japanese).

Ishida, H., Safety assessment method on low-speed running test on sharp curves, RTRI Report, Vol.19, No.9 (2005), pp.5-10 (in Japanese).

Ishino, U., Set-off mechanism, Shinsenro, Vol.70, No.10 (2016), pp.80-81 (in Japanese).

Katou, T. and Yazawa, E., Measurement of wheel load and lateral load from ground, Shinsenro, Vol.53, No.11 (1999), pp.33-35 (in Japanese).

Nishinomiya, Y., Development of the vehicle running simulation method with an explicit dynamic finite element method, Journal of Japan Society of Civil Engineers, Ser. A2, Vol.74, No.2 (2018), pp.649-660 (in Japanese).

Oikawa, Y., Switches and crossings, RRR, Vol.73, No.9 (2016), pp.28-31 (in Japanese).

Railway Technical Research Institute ed., Guidelines for running test for speed up of meter gauged line (1993), p.91 (in Japanese).

Railway Technical Research Institute ed., Design standard for railway structures and commentary-track structures (2012), pp.187-199 (in Japanese).

Sato, Y., Structure and maintenance of switches and crossings (1987), pp.415-417, Japan Railway Civil Engineering Association (in Japanese).

Shimizu, S., Oikawa, Y. and Shiota, K., Construction of method for analytical evaluation of turnout structures, Quarterly Report of RTRI, Vol.60, No.4 (2019), pp.268-273.

Sugiyama, Y., Iwata, K. and Yamamoto, H., Basic study on train control system integrating operational control and security control, RTRI Report, Vol.32, No.5 (2018), pp.35-40 (in Japanese).

Tomii, N., How to make train time tables (2012), p.23, Ohmsha (in Japanese).

Yanagawa, H., Movable set-off mechanism, Sinsenro, Vol.74, No.1 (2020), pp.56-58 (in Japanese). 